\title{
First Occurrence of the Grey Fox, Urocyon cinereoargenteus, in New Brunswick: a Climate-change Mediated Range Expansion?
}

\author{
Donald MCALPInE ${ }^{1}$, James D. Martin ${ }^{2}$ and CADE LibBY ${ }^{3}$
}

$\begin{aligned} & \text { 1New Brunswick Museum, } 277 \text { Douglas Avenue, Saint John, New Brunswick, E2K 1E5 Canada; e-mail donald.mcalpine@ } \\ & \text { nbm-mnb.ca }\end{aligned}$
${ }^{2}$ Department of Fisheries and Oceans. St. Andrews Biological Station, St. Andrews, New Brunswick E5B 2L9 Canada
${ }^{3}$ Fish and Wildlife Branch, Department of Natural Resources, P.O. Box 6000, Fredericton, New Brunswick, E3B 5H1 Canada

McAlpine, Donald F., James M. Martin and Cade Libby. 2008. First occurrence of the Grey Fox, Urocyon cinereoargenteus, in New Brunswick: a climate-change mediated range expansion? Canadian Field-Naturalist 122(2): 169-171.

The first occurrence in New Brunswick of the Grey Fox (Urocyon cinereoargenteus), a threatened species in Canada, is documented based on a $4.3 \mathrm{~kg}$ subadult male trapped in the southwestern corner of the province. This is an approximate range extension of $135 \mathrm{~km}$ from the most northerly Maine occurrence and may reflect a larger North American range expansion underway since 1930-40, perhaps in response to warming climate.

Key Words: Climate change, distribution, Grey Fox, New Brunswick, threatened species, Urocyon cinereoargenteus.

In Canada, the Grey Fox (Urocyon cinereoargenteus) has been assessed as a threatened species (COSEWIC $2002 *$ ). It is estimated that fewer than 250 mature individuals make up the entire Canadian population, although it seems likely that only on Pelee Island, Ontario, does a Canadian breeding population now exist (Judge and Haviernick 2002*). Records from the Rainy River District of Ontario west into southern Manitoba and mainland southeastern Ontario are thought to be dispersing individuals from south of the Canadian border (Judge and Haviernick 2002*). A single Grey Fox trapped near Lake Athabasca, Alberta, in 1950 is considered extra-limital (Moore 1952: Fritzell and Haroldson 1982) or perhaps even an escaped captive (Fritzell 1987). Judge and Haviernick $(2002 *)$ report that there have been no confirmed records of the Grey Fox in Quebec in over 100 years and that all Canadian reports of the Grey Fox from the past 20 years have been from Ontario. Here we document the first specimen of the Grey Fox in New Brunswick, placing this occurrence in the context of a range expansion underway since 1930-1940 that is perhaps the result of a warming climate.

On 29 October 2007 JDM trapped a Grey Fox on the west side of the Digdeguash River $0.75 \mathrm{~km} \mathrm{NNW}$ of Rollingdam, Charlotte County, New Brunswick $\left(45.320^{\circ} \mathrm{N}, 67.075^{\circ} \mathrm{W}\right)$. The location is approximately $34 \mathrm{~km}$ east of the Maine-New Brunswick border and about $135 \mathrm{~km}$ northeast of the most northerly Maine Grey Fox sighting reports from just north and northeast of Bangor (W. Jakubas, personal communication to DFM). The fox was taken in a 330 body-gripping conibear trap set for Beaver (Castor canadensis) on a trail about $1 \mathrm{~m}$ from the water's edge $0.35 \mathrm{~km}$ west of Rollingdam Road. The site is in mixed forest dominated by Balsam Fir (Abies balsamea), poplar (Populus sp.) and Grey Birch (Betula populifolia). There are many commercial blueberry fields in the area, and woodlots nearby have been selectively cut.
Measurements of the specimen are as follows: total length $1001 \mathrm{~mm}$, tail vertebrae $304 \mathrm{~mm}$, hind foot $125.4 \mathrm{~mm}$, ear $61.2 \mathrm{~mm}$, weight $4.3 \mathrm{~kg}$, testes both about $13.5 \mathrm{~mm} \times 3.0 \mathrm{~mm}$. The animal was judged to be subadult on the basis of degree of closure of skull sutures, tooth wear, and mean eye lens weight $(81.15$ mg), after Wood (1958) and Lord (1961). The full stomach contained the remains of a Ruffed Grouse (Bonasa umbellus). Seven adult cestodes of Taenia pisiformis were removed from the upper small intestine. The skin, skeleton, and eye lenses have been deposited in the New Brunswick Museum mammal collection (NBM 6212) and vouchers of T. pisiformis are now in the NBM invertebrate collection (NBM 7172).

Fitzell (1987) has noted that knowledge of dispersal movements is important in understanding Grey Fox population dynamics. In Alabama dispersal movements of juvenile Grey Foxes start in October, with this behaviour most pronounced in males. The New Brunswick record reported here clearly fits the pattern of a postnatal dispersal movement but suggests that these movements can on occasion be greater than the maximum of $84 \mathrm{~km}$ reported by Sheldon (1953). Buechner (1944) reports a mean infection rate of $9.6 T$. pisiformis per Grey Fox. The presence of adult T. pisiformis strongly suggests feeding on a lagomorph (Jones and Bybus 2001); Elleker (1984*) recorded an infection rate of $85 \%$ for larval T. pisiformis in Varying Hares (Lepus americanus) in southern New Brunswick. Adults of this cestode are generally frequent in canids (Miller and Harkema 1968).

Archaeological evidence demonstrates that before European settlement of eastern North America the Grey Fox was a common mammal in southern Ontario and, in the east ranged north to at least Cumberland County, in southwestern Maine (Wintemberg 1921; Palmer 1956). For reasons that remain unclear, about 350 years ago the species disappeared from the northern portion of its range in eastern Canada, northern 
New England, and some of the Great Lakes states. However, since 1930-1940 the Grey Fox has re-occupied areas north and east of central New York and Connecticut and perhaps even expanded what was its historic range in New England, the Midwest, Ontario, and Manitoba (Fritzell and Haroldson 1982; Judge and Haviernick $2002 *$ ). It has been suggested that the current range expansion may be the result of a general warming trend since 1850 (Waters 1964); in Wisconsin and Minnesota this climate-mediated range expansion may be as recent as the 1990s (Judge and Haviernick 2002*). Palmer (1956) implicates the spread of cottontail rabbits (Silvilagus sp.), a prime prey species for the Grey Fox (Fritzell and Haroldson 1982), and the replacement of woodland with agricultural habitats, in the species range expansion in the northeast. However, it should be noted that the most northerly sighting reports of Grey Fox in Maine are now beyond the range for Sylvilagus transitionalis in that state and that the range of the New England Cottontail in Maine is now contracting, apparently in response to forest maturation (Boone and Krohn 1998*). Conversely, Boone and Krohn (1998*) report that Grey Fox numbers in Maine appear to be increasing in response to this factor. Fritzell (1987) also emphasizes that changes in land use, including agricultural activity in the northeast, have created conditions that favour the Grey Fox. Although several studies have shown that the Grey Fox has a preference for old fields (Fritzell and Haroldson 1982), the species is closely associated with deciduous forest and especially forest edge habitats (Fritzell 1987).

Recent trapping records for Grey Fox in Maine suggest that the species remains concentrated in the southern counties, including and north of Cumberland. This latter county is where Palmer (1956) documented the first recent (1955) Maine occurrence. However, Maine fur harvest records also suggest a now well-established Grey Fox population with an average of 134 pelts/ year (range 67-196) taken in the state from 20012002 through 2006-2007. Clearly, Grey Fox numbers have increased dramatically in Maine during the past 50 years (Boone and Krohn 1998*). Occurrence of the Grey Fox in New Brunswick appears to be part of this northward expansion in population and range that has been underway in Maine for the past half-century. It also reflects a more general North American reoccupation and expansion in range for the species since 1930-1940. Although Judge and Haviernick (2002) report that there have been no confirmed records of the Grey Fox in Quebec in over 100 years, this may be incorrect. Although the Grey Fox is certainly still very rare in southern Quebec, current information indicates the Grey Fox is present in Quebec in the region near Lacolle $\left(45.09^{\circ} \mathrm{N}, 43.37^{\circ} \mathrm{W}\right)$, about $8 \mathrm{~km}$ north of the Vermont border. Although trapping this species in Quebec is prohibited, about one Grey Fox has been taken accidentally in the Lacolle region each year over the past five years (D. Blanville, personal communication to DFM).

Judge and Haviernick (2002*) suggest that a warming climate should make Canada more attractive to the Grey Fox in the coming decades. Coupled with this milder weather is a predicted shift in northeastern North America towards a forest dominant by deciduous tree species and a loss of spruce-fir habitat (Iverson and Prasad 2001). Both of these factors should favour the Grey Fox in the region in the future.

\section{Acknowledgements}

We thank Dr. Walter Jakubas, Maine Department of Inland Fisheries and Wildlife, for his help in securing current information on the status of the Grey Fox in Maine and for supplying Maine fur harvest records.

Documents Cited (marked $*$ in text)

Boone, R.B., and W. B. Krohn. 1998. Maine GAP analysis vertebrate data-part 1: Distribution, habitat relationships, and status of amphibians, reptiles, and mammals in Maine. Maine Cooperative Fish and Wildlife Research Unit, Department of Wildlife Ecology, University of Maine, Orono, Maine.

COSEWIC. 2002. COSEWIC assessment and update status report on the Grey Fox, Urocyon cinereoargenteus interior in Canada. Commitee on the Status of Endangered Wildlife in Canada. Ottawa., Ontario.

Ellerker, J. L. 1984. Survey of the intestinal helminthes of the Eastern Coyote (Canis latrans var.) in New Brunswick. Unpublished MSc thesis. University of New Brunswick.

Judge, K. A., and M. Haviernick. 2002. Updated status report on the Grey Fox Urocyon cinereoargenteus in Canada, in COSEWIC assessment and update of Status Report of the Grey Fox Urocyon cinereoargenteus interior in Canada. Commitee on the Status of Endangered Wildlife in Canada. Ottawa.

\section{Literature Cited}

Buechner, H. K. 1944. Helminth parasites of the Gray Fox. Journal of Mammalogy 25: 185-188.

Downing, S. C. 1946. The history of the Gray fox in Ontario. Canadian Field-Naturalist 60: 45-46.

Fritzell, E. K. 1987. Gray Fox and Island Gray Fox. Pages 409-420 in Wild Furbearer Management and Conservation in North America. Edited by M. Novak, J. A. Baker, M. E. Obbard and B. Malloch. Ontario Trappers Association, North Bay, Ontario.

Fritzell, E. K., and K. J. Haroldson. 1982. Urocyon cinereoargenteus. Mammalian Species number 189: 1-8.

Iverson, L. R., and A. M. Prasad. 2001. Potential changes in tree species richness and forest community types following climate change. Ecosystems 4: 189-199.

Jones, A., and M. J. Bybus. 2001. Taeniasis and echinococcosis. Pages 150-192 in Parasitic diseases of wild mammals. Edited by W. M Samuel, M. J. Bybus and A. A. Kocan. Iowa State University Press, Ames, Iowa.

Lord, R. D. 1961. The lens as an indicator of age in the Gray Fox. Journal of Mammalogy 42: 109-111.

Miller, G. C., and R. Harkema. 1968. Helminths of some wild mammals in the southeastern United States. Proceedings of the Helminthological Society of Washington 35: 118-125. 
Moore, J. E. 1952. The Gray Fox in Alberta. Journal of Mammalogy 33: 253.

Palmer, R. S. 1956. Gray Fox in the Northeast. Maine Field Naturalist 12: 62-70.

Sheldon, W. G. 1953. Returns on banded Red and Gray Foxes in New York State. Journal of Mammalogy 34: 125.

Waters, J. H. 1964. Red Fox and Gray Fox from New England archaeological sites. Journal of Mammalogy 45: 307308 .
Wintemberg, W. J. 1921. Archaeological evidence concerning the presence of the Gray Fox (Urocyon sp.) in Ontario. Canadian Field-Naturalist 35: 19-20.

Wood, J. E. 1958. Age structure and productivity of a Gray Fox population. Journal of Mammalogy 39: 74-86.

Received 31 January 2008

Acepted 17 February 2009 